\title{
Complimenting As A Conversation Opener: A Strategy In Teaching English Speaking Proficiency
}

\author{
Yohannes Telaumbanua \\ English Department, State Polytechnic of Padang \\ E-mail: yohannes_telaumbanua@yahoo.com
}

\begin{abstract}
The speech act of paying compliment ("you are looking good") to someone is the attempt to establish the social relationship and ties solidarity between the communicators. In addition, it attributes credit to someone other than the speaker; usually the person addressed, for some "good" (possession, characteristic, skill, etc.) which is positively valued by the speaker and the hearer. Furthermore, the act of responding it is an interlocutor's acceptance ("Thanks, Thank you") and non-acceptance ("it is really quite old") of the compliments. In conjunction with English teaching and learning process, the attempt to compliment and respond it can be used as a strategy to help the EFL learners able to open a conversation or a short talk with their classmates. The EFL lecturers/teachers will bridge the learners to strike up their conversations/short talks by providing some conversations/short talks' situations. The situations, which relate to their friends' possessions, characteristics, or skills, are used to attribute their credits as conversation opener.
\end{abstract}

Keywords — compliment, compliment response, acceptance, non-acceptance

\section{INTRODUCTION}

To most people, mastering the art of speaking is the single most important aspect of learning a second or foreign language, and success is measured in terms of the ability to carry out a conversation in the target language (Nunan: 1991). Learning to speak a foreign language requires more than knowing its grammatical and semantic rules. Leaners must also acquire the knowledge of how native speakers use the language in the context of structured interpersonal exchange, in which many factors interact. Therefore, it is difficult for EFL learners, especially adults, to speak the target language fluently and appropriately (Richards and Renandya: 2002). Speaking a language is especially difficult for foreign language because effective oral communication requires the ability to use the language appropriately in social interactions. Diversity in interaction involves not only verbal communication but also paralinguistic elements of speech such as pitch, stress, and intonation. In addition, nonlinguistic elements such as gestures and body language/posture, facial expression and so on may accompany speech or convey messages directly without having any accompanying speech though there is tremendous variation crossculturally and cross-linguistically in the specific interpretations of the gestures and body language. Besides, different cultural assumptions about the purposes of particular interactions and expected outcomes of encounters also affect communication (Brown (1994) and Richards and Renandya (2002)).

As a result, owing to minimal exposure to the target language and contact with native speaker, adult EFL learners in general are relatively poor at spoken English, especially regarding fluency, control of idiomatic expression and understanding of cultural pragmatics. Few can achieve nativelike proficiency in oral communication (Brown (1994), and Richards and Renandya (2002)) 
According to (Richards and Renandya: 2002) EFL learners need explicit and clear instruction in speaking, which, like any language skill, generally has to be learned and practiced. However, in practice, it is too often assumed that spoken language skill can be developed simply by assigning students general topics to discuss or by getting them to talk on certain subjects. Evidently, not sufficient strategy is used to facilitate or inhabit them in producing spoken language. For that reason, in order to assist the EFL learners in improving their English speaking proficiency, the EFL teachers/instructors should set an active teaching strategy to elicit larger achievement gains than do others by providing instruction with plenty of purposeful, content-centered interaction among teachers/instructors and learners (Guillaume, et al: 2007). Setting a dynamic English teaching and learning strategy for EFL learners as well as helping them able to communicate the language appropriately in social interactions, the the EFL teachers/instructors is suggested to use compliment and compliment responses as an access to improve the EFL learners' English speaking proficiency.

A way to entail the EFL learners to speak English communicatively is to apply compliment and compliment response as an active teaching strategy in improving the EFL learners' English speaking proficiency. Linguists and language researchers have studied the functions of compliment and compliment response in social language communication. Firstly, as stated by Holmes (1988) the function of compliment is to oil or lubricate the social wheels, paying attention to positive faces one and thus increasing or consolidating solidarity between people. It correspondingly may serve as positive politeness strategies in the context of a face threatening act. Secondly, complimenting is a tool for establishing friendship that creates ties of solidarity. It also is an important social strategy which functions as an opener for conversations and allow meaningful for social interaction to follow (Ishihara, 2003:3). Thirdly, the same idea stated by David (1999) defines that compliments are primarily aimed at "maintaining, enhancing or supporting the addressee's face". Giving and responding to the compliment are complimenters' and respondents' behavior to negotiate social identities and relationship. Fourthly, Wolfson (1983) in Lien
(1993) compliment can serve different functions or replace other speech acts. The data of Lien's study proved that compliment in both English and Vietnamese can be used as an encouragement or used to express or accompany gratitude.

From these descriptions above, it can be concluded that the functions of compliment and compliment response can be used as an active English speaking or conversation teaching strategy by having each student to pay a compliment and then the compliment responded by her / his interlocutor. Through this strategy, the EFL learners can open their English conversation/speaking naturally, culturally and contextually. In addition, According to Diaz-Rico (2004) EFL learners need opportunities to talk in natural interactional contexts and for variety of purposes: to establish and maintain social relationships; to express reactions; to give and seek information; to solve the problems; to discuss ideas; to teach and learn a skill; to entertain or play with language; to display achievement. What is more, they need to learn to interact with variety of conversational patterns: other students, the teachers, other adults at schools, college, cross-age peers, guests and so on. Therefore, the reason to choose this topic is meant to teach this strategy in order the EFL learners have huge opportunities to talk in natural interactional contexts and for variety of purposes as well as to learn to interact with variety of conversational patterns. The teaching of compliment and compliment response as an active teaching strategy focuses on Indonesian learners' performance of speech events.

\section{LITERATURE REVIEWS}

\section{A. Speech Acts}

Speech act is a technical term in linguistics and the philosophy of language. The contemporary use of the term goes back to J.L. Austin's (1962) discovery of performative utterances and his theory of locutionary, illocutionary, and perlocutionary acts. Speech acts are commonly taken to include such acts as promising, ordering, greeting, warning, inviting and congratulating (Fromkin and Rodman: 1988). In addition, speech acts is the study of how one does things with 
sentences. Furthermore, in studying speech acts, one is aware acutely of the importance of the context of the utterance. Furthermore, speech acts is the study of how to do things with words. In other words, speakers are attempting to finish an act with word performing speech act. Actually, speech act is firstly proposed by Austin which stated that the intention to many functions performed by utterances of as part of interpersonal communication. One out of some functions of the speech acts is to pay compliment and responses to the compliment. The act of paying compliment to someone is the attempt to establish the social relationship between the communicators (Fromkin and Rodman: 1988).

One performs speech acts when she offers an apology, greeting, request, complaint, invitation, compliment, or refusal. A speech act is an utterance that serves a function in communication. A speech act might contain just one word, as in 'Sorry!' to perform an apology, or several words or sentences: "I'm sorry I forgot your birthday. I just let it slip my mind or compliment: 'Hey, I really like your tie!'. Speech acts include real-life interactions and require not only knowledge of the language but also appropriate use of that language within a given culture (Fromkin and Rodman: 1988). Furthermore, speech acts is the study of how to do things with words. In other words, speakers are attempting to finish an act with word performing speech act. Actually, speech act is firstly proposed by Austin (1962) which stated that the intention to many functions performed by utterances of as part of interpersonal communication. One out of some functions of the speech acts is to pay compliment and responses to the compliment. The act of paying compliment to someone is the attempt to establish the social relationship between the communicators (Fromkin and Rodman: 1988).

\section{B. Patterns of Compliment}

In most speech communities, the speech act of complimenting is a well-established politeness strategy. While the giving of and responding to compliments can be regarded as rather universal across different languages and cultures, the form, frequency and function of compliments and compliment responses significantly varies (Lewis: 2003). In her paper, she compares English compliment responses to realizations of the same speech act in Chinese and German. She states that since the 1970s, sociolinguists have turned towards research on communicative competence, thereby focusing on native speaker's performance of speech acts (e.g. compliments, apologies, requests, complaints etc.).

In the last three decades, the speech event of complimenting and compliment responding has been one of the major areas on which sociolinguistic research has focused on. There are extensive studies on this respective speech act in American English (e.g. Pomerantz 1978, Manes and Wolfson 1980 in Lewis 2003) as well as comparative cross-cultural research on complimenting behavior, examining the differences in speech act realization between variants of English (American /Irish , e.g. Schneider 1999; American /South African, e.g. Herbert 1989 in Lewis 2003), and between English and other languages (Chinese, e.g. Chen 1993; German, e.g. Golato 2002 in Lewis 2003). These studies of communicative competence make apparent that communicating effectively and efficiently in a language requires more than just linguistic knowledge; the ability to use this linguistic knowledge appropriately in the given sociocultural context is also essential. Learners with insufficient pragmatic knowledge frequently transfer patterns from their native language into the foreign language. Second language teaching profits from studies in communicative competence because it provides teachers with information on realization strategies concerning certain speech acts in different languages (Lewis: 2003).

According to Holmes (1998) a compliment is a speech act which explicitly or implicitly attributes credit to someone other than the speaker; usually the person addressed, for some "good" (possession, characteristic, skill, etc.) which is positively valued by the speaker and the hearer. For example, we would count "You're looking good" and "Is that a new suit" as compliments. Although responses to a compliment may be various, there is relatively a strong agreement within a certain speech community as to what form constitutes a "correct response". It is proven that the most general response to a compliment is "Thank you" in western societies. Despite the strong awareness of the prescriptive form, many speakers still feel embarrassed by compliments and feel uncomfortable when they respond to compliments. Clearly, this paradox merits investigation.

According to Searle's classification of speech act in Lien (1993:196) the complimenting speech act can be classified as expressive. When the speaker is complimenting, she or he expresses his 
or her opinion, or comment to someone about something which is, in the speaker's opinion, nice or good. compliments is positive expression or evaluation, which is directed either explicitly or implicitly to someone for something valued positively by the speaker and hearer and even the whole speech community (Kasper and Zhang: 1995:5). In addition, Lien (1993:196) compliment is an expression of admiration, approval or compliment can be defined as a favorable judgment, or opinion, saying something nice to another individual. In conclusion, compliment is an expression expressed for something good or for the ability she/he has or some other triggers that make the speaker admire him or her.

According to Holmes (1988:486) in Lien (1993:197) compliment consists of two classifications. The first classification is direct compliment. Direct compliment is expressed to the person being complimented about his/her possession or ability, for example, "Mm, you've got a new jumper. It's beautiful!". The second is indirect compliment is clearly addressed to one person but actually compliment another party who is present, for example, "Your friend seems very nice, dear". Manes and Wolfson in Lien (1997:197) states that compliment consists of two categories. The first is compliment on personal appearance. Compliment on personal appearance is compliments giving on someone's features, clothes, and home, automobile and so on, for example, "Hey, that's a nice jumper". The second is compliment on work done: compliment on someone's skill, talent, personal quality or taste, for example, "Is that the chest you made? You really did a good job. This is really nice". In conjunction with it, Lien (1993:197) presents the patterns of compliment which consists of three elements. The first is Pre-head is an expression preceding compliment, e.g. $\mathrm{mm}$, you have got a new jumper. The second is Head act is compliment, e.g. it is beautiful and the third is Post head is expression following compliment, e.g. keep practicing. On the contrary, there are six types of Pre-Head Act in Indonesian as follows (Thaib, 1993:9)

TABLE I

PRE - HEAD ACT IN INDONESIAN DATA

\begin{tabular}{|l|l|l|}
\hline No & Pre - Head Act Types & Sentence \\
\hline
\end{tabular}

\begin{tabular}{|l|l|l|}
\hline 1. & $\begin{array}{l}\text { Term of addressee } \\
\text { Wah }+ \text { (term of }\end{array}$ & $\begin{array}{l}\text { reference item } \\
\text { (partial) Suzan... }\end{array}$ \\
3. & Addressee) & Wah...Aidil ... \\
4. & Oh $+($ name $)$ & Oh...Jack... \\
5. & Aduh + (name) & Aduh...Jack... \\
6. & Ah $+($ name $)$ & Ah...Jack \\
& Eh $(\mathrm{hm})+($ name $)$ & Eh $($ hm)...Jack... \\
\hline
\end{tabular}

\section{Head Act in Indonesian Data}

It is beautiful / it is pretty

That's so nice

This is delicious / it is yummy

It is good

That's great

It is interesting

It is brilliant (Thaib, 1993:9)

2. Post - Head Act in Indonesian Data

The complimenters can use WH questions (when, where, whom, how, why, which, etc) questions forms to obtain information of the complimenting objects. These questions can be grouped into five categories as shown in the table below (Thaib, 1993:10).

\begin{tabular}{|c|c|c|}
\hline No & Types of Questions & Sentences \\
\hline 1 & Dimana (Where).....? & $\begin{array}{l}\text { Kamu pintar sekali main } \\
\text { gitar. Belajar dimana? } \\
\text { (You play the guitar well. } \\
\text { Where did you learn?) }\end{array}$ \\
\hline 2 & Kapan (When).....? & $\begin{array}{l}\text { Kamu pintar sekali main } \\
\text { gitar. Kapan belajarnya? } \\
\text { (You play the guitar well. } \\
\text { When did you learn it?) }\end{array}$ \\
\hline 3 & Bagaimana (How)......? & $\begin{array}{l}\text { Ikannya enak sekali. } \\
\text { Bagaimana cara } \\
\text { memasaknya? } \\
\text { (The fish is very delicious. } \\
\text { How did you cook it?) }\end{array}$ \\
\hline 4 & $\begin{array}{l}\text { Berapa lama (How } \\
\text { long)? }\end{array}$ & $\begin{array}{l}\text { Bahasa Prancismu lancer } \\
\text { sekali. Belajar berapa lama? } \\
\text { (Your French is fluent. How } \\
\text { long have you learned it?) }\end{array}$ \\
\hline 5 & $\begin{array}{l}\text { Dengan siapa (with } \\
\text { whom)......? }\end{array}$ & $\begin{array}{l}\text { Kamu main gitar pintar } \\
\text { sekali. Belajar dengan } \\
\text { siapa? } \\
\text { (You play the guitar well. } \\
\text { With whom did you learn?) }\end{array}$ \\
\hline
\end{tabular}

For that reason, Herbert (1986) demonstrates that compliments are used to "negotiate solidarity with the addressee". Their aim is to make the 
addressee feel good and their formulaic nature minimizes the chance that they will be misinterpreted by the addressee.

\section{Types of Compliment Response}

The followings are the compliment response types of (1) acceptance and (2) non-acceptance (Herbert: 1990).

\section{Acceptance}

Comment history is addressee offers a comment(s) on the object complimented, for example: I bought it for a trip to Arizona

Transfer or Reassignment is addressee agrees with the compliment assertion, but the complimentary force is transferred to the third person, for example:

My brother gave it to me.

Comment Acceptance is addressee accepts the complimentary force and offers a relevant comment on the appreciated topic, for example: Yeah...it is my favorite, too.

Praise upgrades is addressee accepts the compliment and state that the compliment force is insufficient, for example: Really, brings out the blue in my eyes, doesn't it?

Appreciation Token is a verbal or non-verbal acceptance of the compliment, for example: Thanks, Thank you.

\section{Non Acceptance}

Scale Down is addressee disagrees with the complimentary force, pointing to some flaw or fault in the object or claiming that the praise is overstated, for example: It is really quite old.

Questioning (Response) is addressee questions the sincerity or the appropriateness of the compliment, for example: Do you really think so?

Disagreement is addressee questions the insincerity or the inappropriateness of the compliment, for example: I hate it

\section{Function of Compliments}

The functions of complimenting are varied. People may compliment one another to maintain or re-establish a social relationship, to reinforce a desired action (e.g., teacher-student interaction), or to soften a speaker's discourse before uttering a face threatening act (FTA) maintained that compliments appeared to be functionally complex speech acts which served as "solidarity signals, commenting on friendships, attenuating demands, smoothing ruffled feathers and bridging gaps created by possible offenses". Compliments are usually intended to make others feel good. The primary function of a compliment is most obviously affective and social, rather than referential or informative. They are generally described as positively affective speech acts serving to increase or consolidate the solidarity between the speaker and addressee. In brief, compliments have been said to "grease the social wheels" and thus to serve as "social lubricants" that create or maintain rapport Wang and Tsai (2002 and 2003).

\section{PROCEDURE OF TEACHING COMPLIMENT AND COMPLIMENT RESPONSE}

The procedure of teaching compliment and compliment response in striking English students' conversation/speaking up is as follows (the following handout is adopted from Mannes and Wolfson (1981), Billmyer (1990) and Dunham (1992) in Ishihara (2012)).

\begin{tabular}{|c|c|}
\hline Language Level: & High intermediate level, \\
\hline Language: & Adult ESL Learners \\
\hline Grade Level & Freshmen \\
\hline Focus LLS & $\begin{array}{l}\text { Compliment and Respond to the } \\
\text { Compliment }\end{array}$ \\
\hline Time: & 40-50 minutes per lesson \\
\hline Resources: & $\begin{array}{l}\text { Handouts adapted from Manes \& Wolfson } \\
\text { (1981), Billmyer (1990), Dunham (1992) } \\
\text { in Ishihara (2011) and Chamot et al (1999) }\end{array}$ \\
\hline
\end{tabular}

\section{A. Description of the Activity}

In the speaking exercise (a 'mingling' activity), EFL learners practice giving and receiving compliments. They form two concentric circles, facing a partner. The students in the outside circle look at their partner. Then, they find some nice quality on which to compliment them, and then give a compliment. The students in the inside circle respond to the compliment. The circles then move over by one person (the students change partners), and they repeat the exercise. When they have completed the circle, they switch roles and go around again. Advise the students that they do not always have to accept compliments; they can express themselves in the way most comfortable to them, including, perhaps, using a deflection strategy such as downgrading, questioning, or 
shifting credit. This activity functions as a good springboard for even more learner-initiated practice since learners generally start complimenting each other for pleasure before and after class. After studying the function of complimenting as a conversation opener, learners also practice initiating a conversation with compliments, extending the topic, and sustaining the conversation.

\section{B. Procedures}

\section{1) Preparation:}

a. Greeting and General warm-up

b. Introduce the concepts of compliment and compliment response

c. Teach related vocabulary of of compliment and compliment response (e.g., compliment/butter up/apple polish).

d. Present a sample dialogue of complimenting between instructors.

e. Initial inventory, have students individually complete the following pre-instruction inventory How often do you hear people complimenting each other?

What do people say and how do they respond to compliments?

Do you give and/or receive compliments in English? Are you always comfortable with the way you exchange compliments? If no, when do you feel uncomfortable and why?

What do people say when they give and receive compliments in your country? Provide a literal translation of some examples.

What do people compliment others on?

Who is more likely to exchange compliments?

\section{2) Presentation}

a. Giving a Compliment

Tell to the EFL learners that compliment and compliment response for language learning speaking activity can be very useful strategy in opening a conversation or short talk. Often giving a compliment is a reflex. The following is an example to give a compliment to our interlocutor. The automatic nature of "You look great" keeps our focus on what we see and not much more. This model will surely get women thinking about waiting a beat or two before saying "I love your hair" so that they can give a compliment that means so much more. The first compliment we thought of is one we often tell our best friend: "You're a really great mom. Really." And for those outstanding women without kids, "You would make a really great mom") another favorite compliment, to give and get, is: "You inspire me.”(Patch, Elizabeth: July 23rd, 2011).
Have EFL learners to enact good examples with each other and practice complimenting in pairs.

To prepare for the teaching of compliment responses, have learners sincerely compliment their interlocutors and then jot down their responses immediately after each conversation.

\section{b. Responding a Compliment}

Here is an example of how to respond a compliment: Imagine that you are in this situation.

You are cooking and your roomie told you that it looked/smelled really good. A couple of thoughts floated through your head. "Yea, I'm an amazing cook." "It's just good ingredients." "Cooking is really big in my family; my mom taught me everything." "I hope it's good." None of these really work for me. Blame a false sense of humility, the ego, or whatever. None of those responses capture what I want to say, "Thank you, God has blessed me with a wonderful family that taught me how to cook and tonight he provided excellent ingredients and gave me the insight to make a delicious meal. It's nothing, yet everything at the same time. And anyone can do it." That seems a little much to say, especially if I start doing something similar for every compliment. I think I just said yea and offered some to her. Any help? (Bravy:2012)

Respond: Thanks very much

Model short exchanges between instructors using "responses to compliments" (teacher resource).

Teach four self-praise avoidance strategies (downgrading the compliment, questioning the compliment, shifting the credit away from themselves, and returning a compliment) as types of responses that deflect compliments.

\section{3) Practice}

Practice giving and responding to compliments in a mingling activity. Students form two concentric circles, each facing a partner. One compliments the other, who responds. The outer circle rotates and each student finds a new partner and repeats the process; the circles switch roles after practicing sufficiently.

Model the conversation with compliments as openers (Teacher Resource).

Have learners highlight topics, point out the rapidly shifting topics, and identify the conversation-opener function of complimenting.

Have learners in pairs practice opening a conversation with a compliment and develop it.

\section{4) Evaluation}

Ask the volunteer to compliment and respond a compliment

Do they focus on subject complimented?

Do they respond the compliment correctly?

\section{5) Expansion}


Teach the EFL learners compliment and respond a compliment in the target language

Have the EFL learners create their compliment and respond a compliment and hang it in the classroom.

\section{CONCLUSIONS}

In conclusion, complimenting is a means of communication which can be used to establish social rapport which automatically creates good solidarity among speakers and interlocutors. It also is an important social strategy which functions as an opener for a conversation and allows meaningful social interaction to follow. Compliment can be used as well in the English teaching speaking or conversation class by providing speaking/conversations' situations. The situations provided must relate to the EFL learners friends' possessions, characteristics, or skills. The possessions, characteristics, or skills will be a media for the EFL learners to attribute their credit to their interlocutors. From this media, the EFL learners will compliment and then responded. This contact will create good atmosphere between speakers and hearers which indirectly create and open a conversation or short talk.

\section{REFERENCES}

[1] Austin, J.L. 1962. How To Do Things With Words. Oxford. Clarendon Press.

[2] Bravy, Ariel. 2012. How Should You Respond To Compliments? http://www.youaretrulyloved.com/enlightenment/how-should-yourespond-to-compliments/

[3] Brown, H.D. 1994. Principles of Language Learning and Teaching. Englewood Cliffs, NJ: Printice Hall.

[4] Fromkin, Victoria and Rodman, Robert. 1988. Introduction to Language. New York. Holt Rineheart and Winston, Inc.
[5] Guillaume, Andrea, M. et al. 2007. 50 Strategies for Active Teaching: Engaging K-12 Learners in the Classroom. New Jersey. Pearson Education, Inc.

[6] Herbert, Robert .K. 1990. "Sex-based differences in Compliment Behavior: In Language in Society" 19:204-224

[7] Herbert, K. (1986). "Say "thank you" or something: American Speech" 61(1), pg. 76-88. Retrieved April 13, 2006 from the JSTOR database.

[8] Ishihara, Noriko. December 23. 2011. Giving and Responding to Compliments: Education and Culture. Exchanges.state.gov/media/oelp/teaching-pragmatics/giving.pdf.

[9] Holmes, J. 1988. "Paying Compliment: A Sex Preferential Politeness Strategy in Peer-Review Texts" Journal of Pragmatics. 12.445-556. Kasper, G. and Dahl, M. 1991.

[10] Nunan, David. 1991. Language Teaching Methodology: A Textbook for Teachers. London. Pearson Education, Inc.

[11] Patch, Elizabeth. July 23rd, 2011. 10 Ways to Compliment a Woman, without mentioning her looks. http://elizabethpatch.com/2011/07/10ways-to-compliment-a-woman-without-mentioning-her-looks.html.

[12] "Research methods in interlanguage pragmatics". Studies in Second Language Acquisition, 18/21,49-69.

[13] Richards, J.C. and Renandya W.A. 2002. Methodology in Language Teaching. Cambridge. Cambridge University Press.

[14] Kasper and Zhang, 1995. The Speech Event of Complimenting in Chinese. Unpublished paper At the Congress of the Applied Linguistics Association of Australia.

[15] Lien, Thai. 1993. Complimenting in English and Vietnamese. University of Canberra.

[16] Liu, S. 1997. Studies on negative pragmatic transfer in international pragmatics. Guangxi Normal University Journal. Retrieved April 1, 2006, from http://www.gxnu.edu.cn/Personal/szliu/negative\%20pragmatic\%20tr ansfer.doc

[17] Levinson, C. Stephen. 1983. Pragmatics. London: Cambridge University.

[18] Othman, Normala. (June 2011). Pragmatic and Cultural Considerations of Compliment Responses among Malaysian-Malay Speakers. International Islamic University Malaysia. International Islamic University Malaysia

[19] Thaib, Rusdi. 1993. "A Cross Cultural Study on Giving and Responding to Compliment: Australian English vs. Indonesian”. Unpublished paper At the Congress of the Applied Linguistics Association of Australia.

[20] Şükriye Ruhi. (2006). Politeness in Compliment Responses. Journal of Pragmatics 16:1.43-101. International Pragmatics Association.

[21] Yu-Fang Wang and Pi-Hua Tsai [Received 28 October,2002; revision received April 8, 2003 ; accepted April 9, 2003] An Empirical Study on Compliments and Compliment Responses in Taiwan Mandarin Conversation. Taiwan. Providence University National Chengchi University 